\title{
Drying Technologies in Orchids
}

\author{
LC De Singh* and Suman Thapa \\ ICAR-NRC for Orchids, India
}

Submission: September 04, 2017; Published: September 12, 2017

*Corresponding author: LC De Singh, ICAR-NRC for Orchids, Pakyong, Sikkim, India; Email: lakshmanchandrade@gmail.com

\begin{abstract}
Dry flowers are essential export items both in Indian and International markets and Indian export basket composed of $71 \%$ dry flowers which are exported to mainly USA, Japan, Australia, Russia and Europe. The demand for dry flowers is increasing at an impressive rate of 8-10 per cent annually thus offering a lot of opportunities for the Indian entrepreneurs to enter in the global floricultural trade. A number of flowers respond well to drying techniques such as orchids, anemone, zinnia, allium, sweet william, carnation, stock, freesia, narcissus, chrysanthemum, pansy, daffodils, marigold, rose, lilies, foliage like ferns, aspidistra, eucalyptus, ivy, laurel, magnolia and mahonia etc. A number of drying techniques such as air drying, sun drying, press drying, embedded drying, microwave drying, freeze drying, molecular sieve drying and cryo- drying, preservation techniques and value addition of dry flowers with special reference to orchids discussed in details.
\end{abstract}

Keywords: Dry flowers; Embedded drying; Value addition

\section{Introduction}

Dry flowers are essential export items both in Indian and International markets and Indian export basket composed of $71 \%$ dry flowers which are exported to mainly USA, Japan, Australia, Russia and Europe. The demand for dry flowers is increasing at an impressive rate of 8-10 per cent annually thus offering a lot of opportunities for the Indian entrepreneurs to enter in the global floricultural trade Singh [1]. A number of flowers respond well to drying techniques such as anemone, zinnia, allium, sweet william, carnation, stock, freesia, narcissus, chrysanthemum, pansy, daffodils, marigold, rose, lilies etc Rogers [2] and foliage like ferns, aspidistra, eucalyptus, ivy, laurel, magnolia and mahoniaetc Rogers [3]; Healy [4]. Otherwise this industry exports 500 varieties of flowers to 20 countries and export of dried flowers and plants from India is about Rs. 100 crores. Potpourri is a major segment of dry flower industry valued at Rs. 55crores in India alone. This industry provides direct employment toaround 15,000 persons and indirect employment to around 60,000 persons. In India, nearly $60 \%$ of the raw materials are sourced from natural forests and plains, only $40 \%$ of the flowers are cultivated for drying, bleaching and coloring. Orchids are beautiful elegant looking flowers that come in variety of colours and they can be used in flower arrangement or dried flower craft and other value added products.

\section{Harvesting of Materials For Drying}

The flowers should be cut just as they come to maturity Padmavathamma [5]. Flowers harvested at half bloom stage took minimum time for drying Saffeena et al. [6]. The collected materials should be free from surface moisture and dew. Hence it is better to collect the material in the dry season on a sunny day. Flowers or plant parts selected for drying may be sprayed with Dithane Z-78 of Neem based pesticide $(0.5 \%)$.

\section{Moisture Retention After Drying}

Moisture retention in the flowers after drying influences flower shape. Stronger and stiffer petal in dried flowers having low moisture content Chen et al. [7]. A range of 8-11.5 per cent moisture content in the dried flowers will ensure good quality and firmness and maintains keeping quality for more than six months. Excessive drying of flowers resulted into petal shedding during handling Singh [8].

\section{Methods of Drying}

Drying is generally done under artificially produced heat and controlled temperature, humidity and airflow. For removal of water from fresh flowers and plant parts, optimum temperature to be determined, otherwise quality of the product will be affected. The different drying methods are discussed below Bhutani [9].

Air Drying: This is the most common method which is widely used for long lasting seasonal flowers which are crisp in texture. They are hung in an inverted position or kept in an erect manner. Air drying requires a warm clean dark and well ventilated area with low humidity Raghupathy et al. [10]. Flowers may also be spread over blotting sheets/newspapers and kept in dark or in the sun Datta [11]. Among orchids, Vanda 
coerulea, Epidendrumspp, Oncidium 'Taka Yellow', Phalaenopsis and Arundinagraminifolia showed response on air drying.

Sun Drying: Plant material is embedded in drying medium (sand) in a container and exposed to the sun daily to facilitate rapid dehydration. In India, open sun drying is followed for drying many flowers.

Press Drying: The flowers and leaves are placed between the folds of newspaper sheets or blotting paper. To ensure uniform pressure, flowers for press drying should be spread uniformly on blotting paper. These sheets are kept one above the other and corrugated boards of the same size are placed in between the folded sheets so as to allow the water vapor to escape Bhutani [9]. It should be given slight pressure for 24 hours and then kept in an electric hot air oven for 24 hours at 40-45oC Datta [11]. The press dried flowers are stored either in sheets at a dry place or in desiccators for future use. These materials can be used for composing floral craft items like greeting cards, floral designs and other art creations which may be framed for wall pin-ups.

Embedding: The flowers or leaves are embedded in a drying medium, namely, silica gel or borax or white sand depending upon the plant material. Embedding in silica gel is perhaps the easiest and the best method of embedded drying of flowers Table 1: Embedded drying of orchids in oven.
Bhutani [12]; Dhatt et al. [13]; Desh Raj and Gupta [14]. These materials cover flowers in such a way that the original shape of flowers is maintained properly. Metallic or plastic or earthen containers are used for embedding at room temperature in a well ventilated room. About $5 \mathrm{~cm}$ layer of desiccant is poured in the bottom of the container and the flower stems are pushed into the medium.

Flowers are covered and kept at room temperature. After dehydration, the containers are tilted for removing the desiccants over and around the flowers. The dried flowers are either picked up by hand or by tweezers. Embedded drying with borax at 50oC in oven was found successful in Vanda teres, Dendrobiummoschatum, Arundinagraminifolia, Den. 'Madam Pink', Den. 'Lervia', Den. 'A. Abraham', Phal. 'Casa Blanca', Phal. 'Detroit' and Oncidium 'Sweet Sugar' and embedded drying with borax at $60 \mathrm{oC}$ were found successful in Epidendrum spp., Cattleyabowringiana and Cattleya hybrids, Phal. 'Ox Plum Rose x Black Jack' and Den. 'Big White' (Table 1). Embedded drying with borax and silica gel at 550Cin oven was found successful Coelogyneflaccida, Coelogynecristata, Dendrobiumnobile, Dendrobiumwilliamsonii, Dendrobiumaphyllum, Den, 'Erika', Den. 'Big White 4N', Den. 'Bangkok Blue', Paphs. 'Nagasaki' and Cym. 'Sungold' (Table 1).

\begin{tabular}{|c|r|r|}
\hline Sl.No. & Species / varieties & Recommendations \\
\hline 1. & $\begin{array}{r}\text { Vanda teres, Dendrobiummoschatum, Arundinagraminifolia, } \\
\text { Den. 'Madam Pink', Den. 'Lervia', Den. 'Abraham', Phal. 'Casa } \\
\text { Blanca', Phal. 'Detroit' and Oncidium 'Sweet Sugar' }\end{array}$ & Embedded drying with borax at 50oC in oven \\
\hline 2. & $\begin{array}{r}\text { Epidendrum spp., Cattleyabowringiana and Cattleya hybrids, } \\
\text { Phal. 'Ox Plum Rose x Black Jack' and Den. 'Big White'. }\end{array}$ & Embedded drying with borax at 60oC in oven \\
\hline 3. & $\begin{array}{r}\text { Coelogyneflaccida, Coelogynecristata, Dendrobiumnobile, } \\
\text { Dendrobiumwilliamsonii, Dendrobiumaphyllum, Den, 'Erika', } \\
\text { Den. 'Big White 4N', Den. 'Bangkok Blue', Phal.'Nagasaki' and } \\
\text { Cym. 'Sungold'. }\end{array}$ & Embedded drying with borax and silica gel at 55oC in oven \\
\hline 4. & $\begin{array}{r}\text { Dendrobium, Phalaenopsis, Cattleya, Cymbidium, Aranda, } \\
\text { Mokara hybrids }\end{array}$ & Perlite, Perlite + borax and Perlite + Silica gel under room condition \\
(24-25oC and 75-79\%RH)
\end{tabular}

Oven Drying: The drying time can be reduced if the stalks are kept in an oven at an appropriate temperature. The embedded plant material is kept in the hot air oven at a controlled temperature for an appropriate time. But care must be taken in the drying temperature and duration of drying. Electrically operated hot air oven at a controlled temperature of 40-50oC is usually used for drying flowers in an embedded condition. Rapid drying techniques at higher temperatures have been documented by Singh et al. [15], Chen et al. [7]; Raju and Jayanthi [16].

Microwave Oven Drying: The principle behind the microwave oven drying is liberating moisture by agitating water molecules in the organic substances with the help of electronically produced microwaves Bhutani [9]. This is the quickest method of drying. Embedded flowers and foliage in silica gel contained in non-metallic earthenware or glassware 
are kept in such an oven for a few minutes to induce effective drying Bhutani [17]. The standardized time limit should be followed. After the treatment, the containers are taken out and kept at ambient temperature for a particular period, so that the moisture of the container evaporates and the plant material gets fully dried. This process is called 'setting time'. The drying period and the setting time vary with the type of flowers; and it varies from one to four minutes. Setting time vary from 2 to 5 hours. Thomler [18] reported that microwave oven drying was more suited for cluster of florets such as golden rod, gypsophilla and corn flower. White et al. [19] reported that micro wave oven dried flowers looked fresh and more colourful than obtained by other methods.

Freeze Drying: Freeze drying is used for preserving flowers and is particularly popular for wedding bouquet preservation. Petals can also be freeze dried and used for decorations at weddings, dinner parties and other occasions, for decorating cakes and scattering on tables etc. Freeze drying flowers uses a process called lyophilization to lower the temperature of the flowers to below freezing, and then a high-pressure vacuum is applied to extract the water in the form of vapour. The vapour collects on a condensing surface outside the chamber, turns back to ice and is removed. Finally, a gradual temperature rise extracts all remaining 'bound' moisture from the flowers. This process retains the original shape and structure and preserves the flowers. Flowers like Alstroemeria, Amaranthus, Aster, Bird of Paradise, Calla Lily, Carnation, Cattleya Orchid, Daffodil, Dahlia, Delphinium, Dendrobium Orchid, Dianthus, Freesia, Gardenia, Gladiolus, Gypsophilia, Hyacinth, Hydrangea, Iris, Liatris, Lily of the Valley, Lisianthus, Narcissus, Peony, Phaleonopsis Orchid, Rose (all varieties) and Snap Dragon can be freeze dried. Freeze drying techniques have been reported by various workers Dubois and Joyce [20]; Ruth [21]; Brown [22].

Molecular Sieve Drying: Molecular sieve is a material containing tiny pores of a precise and uniform size that is used as an absorbent for gases and liquids. They are metal alumino silicates which have a crystalline structure consisting of an assembly of tetrahedral. To ensure the dehydration of the fresh natural flowers the mixture of organic solvents is poured onto the hole until the level exceeds the level of the flowers by about $2 \mathrm{~cm}$. The water molecules are progressively absorbed into the small cells or pores of the molecular sieve. The receptacle is closed hermetically for a few days. Once dried, the flower reabsorbs a little moisture of atmospheric origin, and this Table 2: Borax drying of orchids in oven.

\begin{tabular}{|c|c|c|}
\hline Name & Temperature & 36 hours \\
\hline Vanda teres & $50 \mathrm{oC}$ & 60 hours \\
\hline Den. 'Madam Pink' & $50 \mathrm{oC}$ & 180 hours \\
\hline Phal. 'Casa Blanca' & $50 \mathrm{oC}$ & 180 hours \\
\hline Phal. 'Detroit' & $50 \mathrm{oC}$ & 60 hours \\
\hline Den. 'Lervia' & $50 \mathrm{oC}$ & 60 hours \\
\hline Den. moschatum & $50 \mathrm{oC}$ & \\
\hline
\end{tabular}

increases its suppleness and its plasticity. Flowers which are particularly suitable for such a treatment are roses, peonies, camellias, marigolds, globe flowers, orchids, dahlias, carnations, phloxes, summer chrysanthemums, hollyhocks, and the like, and other species with many petals or a fairly rigid structure.

Cryo Drying: The fully open flowers are cut into a uniform $15 \mathrm{~cm}$ length and placed in vials so that the basal $5 \mathrm{~cm}$ is immersed in solution of glycrerine, clove oil, ethylene glycol, dimethyl sulphoxide and wetting agent. After that the flower stems are re cut to $5 \mathrm{~cm}$ in length and placed in a freezing temperature at $-80 \mathrm{oC}$ for 12 hours. Then the flowers are immediately placed in a freeze dryer at $20 \mathrm{oC}$ under a vacuum of less than 100 microns for 7 days. A minimum of 7 days is required for the flower and stem tissues to be totally dry.

Drying With Glycerine: In this method, the angular cut stem ends of berries and leafy material can be dried with their lower ends dipped in a mixture of 1:4 glycerine and water for 3 to 6 days for soft stems and 6 weeks for woody stems. Many types of foliage have been successfully preserved by either immersing leaves or placing crushed stems in a 33 per cent glycerol solution. Being an osmotic agent, glycerine replaces the water content of the tissues Joyce [23]. After treating with glycerine, the plant

Silica Gel Drying: The ground crystals of silica gel are placed in a layer, and then of flowers are kept and the flowers are kept with crystals in a tin container or jar that can be covered. Within 2 to 3 days, the crystals will turn pink and the flower heads will be farm to the touch. At this point, the dried flowers are removed. The silica gel can be re-used.

Borax Drying: Borax is best suited for dehydration of delicate flowers. These are best mixed with equal parts of sand. Bhattacharjee and De [24] suggested that borax and alum being light in weight could be used for dehydration of flowers. Borax being hygroscopic in nature might bleach flower petals if embedded for a long time Datta [25]. Smith [26] reported that flowers like rose, aster, carnation, marigold, dahlia, larkspur, geranium, zinnia, chrysanthemum and delphinium could be dried well in borax. Drying through borax will take 2 to 10 days. To prevent spotting, all the desiccants should be removed from the flowers after drying. A mixture of one part of borax to one to three part of corn meal mixture is satisfactory for rapid drying. One table spoon of salt may be added to speed up drying process. Borax drying in orchids is effective at 50oC (Table 2). material can be micro waved. 
International Journal of Environmental Sciences \& Natural Resources

\begin{tabular}{|c|l|c|}
\hline Den. 'A. Abraham' & $50 \mathrm{oC}$ & 60 hours \\
\hline Onc. 'Sweet Sugar' & $50 \mathrm{oC}$ & 60 hours \\
\hline Arundinagraminifolia & $50 \mathrm{oC}$ & 60 hours \\
\hline Epidendrum spp. & $60 \mathrm{oC}$ & 27 hours \\
\hline Blc'; Guanmiau City', Cattleyabowringeana & $60 \mathrm{oC}$ & 21 hours \\
\hline Den. 'Big White' & $60 \mathrm{oC}$ & 9 hours \\
\hline Phal. Ox Plum Rose $\times$ Black Jack & $60 \mathrm{oC}$ & \\
\hline
\end{tabular}

Sand Drying: Fine sand has been found to be the best material for embedding because it is easy to handle, heavy and doesn't react with water vapor Datta [25]. Organic materials and salts are strained from the sand before use. Since sand is heavier, it takes a longer time for drying than the other desiccants. Drying through sand takes four days to two weeks. A mixture of two parts of borax to one part of sand may be used, adding one tablespoon salt to each quart to speed drying. In orchids, embedded sand drying at $50 \mathrm{oC}$ in oven was found successful in Cattleya, Phalaenopsis, Oncidium, and Vanda [27-29].

Other Drying Techniques: Other desiccants used in drying techniques are expanded clay, kitty litter, perlite, dry saw dust, and rice husk and corn starch. Under room condition $25-280 \mathrm{C}$ and $60 \% \mathrm{RH}$ ), perlite, perlite + borax and perlite + silica gel were found successful for drying florets of Phalaenopsis, Cattleya, Dendrobium and Oncidium orchids.

\section{Special Preservation Techniques}

Skeletonizing: This treatment eliminates all tissues but the "skeleton" or veins of leaves. Skeletonized leaves lend an interesting, lacy appearance to dried arrangements. Heavy-textured leaves are the best selects for this method of preservation. Leaves are boiled for 40 minutes in 1-quart water and 2 tablespoons of lye and rinsed in cold water and scraped or brushed the green pulp from the leaves without destroying the network of veins. To lighten the color of the leaf skeletons immersed in a 1-quart water and 2 tablespoon household bleach solution for 2 hours followed by rinsing and drying.

Bleaching: Bleached ornamental plant material provides a striking appearance when arranged with dried or dyed flowers. Bleaching also permits the use of dyes for colouring. Oxidative (Hypochlorite, chlorite and peroxide) and reductive bleaching chemicals (Sulphite and borohydride) are used for bleaching ornamental flowers and foliage. Sodium chlorite is an excellent bleaching agent because it is relatively selective for lignin without damaging fibre. In reductive bleaches, hydrosulphite s (Sodium or zinc hydrosulphite) is cheap and has maximum bleaching power. After bleaching with oxidative or reductive chemicals, yellowing of the plant materials is the main problem. To avoid yellowing, multi-step bleaching i.e., alternating oxidative bleach with reductive bleach creates products with less yellowing. A final wash in a $2 \%$ solution of barium hydroxide, calcium hydroxide, sodium bicarbonate or aluminium sulphate prevents yellowing.
Coloring Dried Flowers: Preserving flowers with their natural colour is essential otherwise it will be essential to improve the colour of the product by adding dyes. A dye is most often added to the glycerine preserving solution to permanently colour the decorative plant materials. Systemic dyes are available for use. They are acidic-anionic dyes, which are combined with water and glycerine to form a preservation solution that is absorbed by fresh cut flowers and foliage through the stem of the plant. Normally $1.5 \mathrm{ml}$ to $5 \mathrm{ml}$ dye/l of solution is prepared. Colorintake and preservation will require 2-8 days.

Sulphuring: It is used to prevent enzymatic colour change. Traditionally, sulphur granules have been burnt for about 2 hours in a closed chamber along with dry flowers. It is very toxic and therefore, it is advised to check relevant safety instructions.

Potpourri: Potpourri is usually a mixture of dried, sweetscented plant parts including flowers, leaves, seeds, stems and roots. The basis of a potpourri is the aromatic oils found within the plant. Two kinds of potpourri can be made - dry and moist. The most common, the dry method, is quicker and easier, but the potpourri does not last as long. Both methods require a "fixative", for absorbing the aromatic oils and slowly releasing them. Herbs such as Artemesia, Thyme, Sage, Rosemary, Basil, Achillea (Yarrow), Lavender, Scented Geranium, Mint, Marjoram, Verbena, Anise and Fennel can be used for scent. The herbs and fruits should be thoroughly dried to prevent mildew.

\section{Uses of Dry Flowers}

Dry and pressed flowers can be used for many purposes. They can be utilized in the best manner for making decorative floral craft items, greeting cards and covers, wall hangings, floral designs, calendars, floral balls, festive decoration and other creative displays. Floral albums may be prepared with these items for identification of plants for botanical studies. A cottage or small scale industry based on floral crafts using dehydrated flowers, leaves, fruits, pods, seeds and other parts in a distinct possibility. Dehydrated plant parts may be arranged aesthetically and covered with plastic or Trans parent glass to protect them from atmospheric humidity, wind and dust. For interior decoration, dry flowers sealed in glass containers may be used. The dry flower industry can be associated with many subsidiary industries like cotton fabrics, terracotta, packaging, cane, basket and glass, jute, iron and brass, ribbons and laces, candles etc. by incorporating one with the other, one can have the benefit of value addition. 


\section{References}

1. Singh HP (2009) Floriculture industry in India: the bright future ahead. Indian Horticulture 54(1): 3-8.

2. Rogers BR (1988) Drying flowers. The Encyclopedia of Everlastings. Michael Friend man Publishing Group USA pp. 199.

3. Rogers J (1967) Flower arranging. Paul Hamlyn, London pp. 152-157.

4. Healey D (1986) the new art of flowers design. Villard Books, USA pp. 144-146.

5. Safeena SA, Patil VS, Naik B, Hemla (2006) Standardization of stage of harvest for better quality of dry flowers of rose. Journal of Ornamental Horticulture 9(3): 224-226.

6. Padmavathamma P (1999) Standardization of drying technique for static cut flowers. MScthesis submitted to UAS, India.

7. Chen W, Gast KLB, Smithey S (2000) The effects of different freezedrying processes on the moisture content, colour and physical strength of roses and carnations. Scientia Horticulture 84(3/4): 321-332.

8. Singh A (2004) Study of dehydration of Zinnia. Indian Journal of Plant Physiology 9(4): 383-387.

9. Bhutani JC (1990) Capturing nature, a way with flower "Everlastings". Indian Horticulture 34(4): 15-19.

10. Raghupathy R, Amuthan G, Kailappan R (2000) Dried flowers: Significance. Kisan World 28: 39.

11. Datta SK (1997) Dehydration of flowers and foliageand floral craft. NBRI Bulletin No 3, EBIS, NBRI, India p. 20.

12. Bhutani JC (1993) Economic potential of dried flowers. Agricultural Marketing 36(1): 43-46.

13. Dhatt KK, Singh Kushal, Ramesh Kumar (2007) Studies on methods of dehydration of rose buds. Journal of Ornamental Horticulture 10(4): 264-267.

14. Desh Raj, Gupta Prashant K (2003) Standardizing dehydration technology for ornamental plant parts of shrubs from mid-hills of Himachal Pradesh. Journal of Ornamental Horticulture 6(4): 357-361.

15. Singh Alka, Dhaduk BK, Shah RR (2004) Effect of different temperature and embedding media on flower dehydration of zinnia (Zinnia linearis Benth). Indian Journal of Horticulture 61(3): 249-252.
16. Raju MS, Jayanthi R (2002) Drying techniques for China aster cut flowers. (Abstract) In: National symposium on Indian floriculture in the new millennium. ISOH, India p. 87.

17. Bhutani JC (1995) Drying of flowers and floral craft. Advances in Horticulture Ornamental Plants 12: 1053-1058.

18. Thomler J (1997) Drying flowers and leaves.

19. White P, Tijia B, Sheehan MR (2002) Drying and preserving plant materials. University of Florida Co-operative Extension Service.

20. Dubois P, Joyce D (1989) Drying cut flowers and foliage. Farm note no 10/89. Western Australian Department of Agriculture p. 3.

21. Ruth (2000) Pollyrosestationers Freeze dried flowers.

22. Brown J (1999) Freeze drying: American Society of Agricultural Engineers, personal communications.

23. Joyce DC (1998) Dried and preserved ornamental plant material not new, but often overlooked and underrated. Act a Horticulture 454: 133-145.

24. Bhattacharjee SK, De LC (2003) Dried flowers and plant parts. In: Advanced commercial floriculture. Avishkar Publishers, India pp. 162173.

25. Datta SK (2001) Dehydration of flowers and foliage in floral crafts. Floriculture 5: 11-12.

26. Smith RC (1993) Methods of preserving flowers. NDSU Extension Service, North Dakote State University of Agriculture and Applied Science, USA.

27. Bhalla R, Sharma B (2002) Dry flowers status, scope and potential. Production and management of flower crops. Division of Floriculture and Landscaping. IARI, India pp. 162-171.

28. Desh Raj (2001) Making floral crafts from forest product of the Himalayas. Indian Horticulture 45: 26-27.

29. Paul D, Shylla B (2002) The art of flower drying. In: Mishra RL and Mishra S (eds). Floriculture Research Trends in India pp. 41-46.

\section{Your next submission with Juniper Publishers will reach you the below assets}

- Quality Editorial service

- Swift Peer Review

- Reprints availability

- E-prints Service

- Manuscript Podcast for convenient understanding

- Global attainment for your research

- Manuscript accessibility in different formats

( Pdf, E-pub, Full Text, Audio)

- Unceasing customer service

Track the below URL for one-step submission https://juniperpublishers.com/online-submission.php 